\title{
FUNCTIONAL NEUROTOXICITY AND TISSUE METAL LEVELS IN RATS EXPOSED SUBACUTELY TO TITANIUM DIOXIDE NANOPARTICLES VIA THE AIRWAYS
}

\author{
Tamara HORVÁTH', Tünde VEZÉR', Gábor KOZMA², András PAPP1 \\ 'Department of Public Health, University of Szeged Faculty of Medicine, Szeged \\ ${ }^{2}$ Department of Applied and Environmental Chemistry, University of Szeged Faculty of Science and Informatics,
}

Introduction and aims - Nanoparticles of titanium dioxide are suspected neurotoxic agents and have numerous applications possibly resulting in human exposure by several ways including inhalation. In the present work, rats were exposed to spherical $\mathrm{TiO}_{2}$ nanoparticles of two different sizes by the intratracheal route. It was investigated how the neuro-functional alterations, detected by electrophysiological and behavioral methods, were related to the concentration of $\mathrm{Ti}$ in the tissue samples and what the influence of the size of the NPs was.

Materials and methods - Rats (young adult Wistar males, 10/group) were exposed to $\mathrm{TiO}_{2}$ nanoparticles of ca. 10 and $100 \mathrm{~nm}$ diameter (suspension medium: neutral PBS with $1 \%$ hydroxyethyl cellulose) by intratracheal instillation in 5 and $18 \mathrm{mg} / \mathrm{kg}$ b.w. dose; 5 days per week for 6 weeks. Controls were instilled with saline, and vehicle controls, with the suspension medium. To see general toxicity, body weight was checked daily, and organ weights were measured at the end of experiment. Grip strength test, to assess motor function damage, was done before and after the 6-week treatment. Finally, the rats were anesthetized with urethane, spontaneous cortical activity and sensory evoked potentials were recorded, then the rats were dissected and tissue samples were taken for Ti level measurement.

Results - Body weight gain indicated no general toxicity, and no significant change in the relative organ weights, except that of the lungs, was seen. However, change of time-to-fall in the grip strength test, and latency of cortical evoked potentials, were altered in the treated groups, indicating functional damage. Correlation of these alterations with the cortical Ti level was dissimilar for the two sizes of nanoparticles.

\author{
FUNKCIONÁLIS NEUROTOXICITÁS ÉS SZÖVETI \\ FÉMSZINTEK PATKÁNYBAN TITÁN-DIOXID- \\ NANORÉSZECSKÉK SZUBAKUT LÉGÚTI \\ ADAGOLÁSÁT KÖVETÓEN \\ Horváth T, MD; Vezér T, MD; Kozma G, MD; Papp A, MD \\ Ideggyogy Sz 2018;71(1-2):000-000.
}

Bevezetés és célkitúzés - A feltételezetten neurotoxikus hatású titán-dioxid-nanorészecskék kiterjedt alkalmazása emberi expozícióval járhat, ami többféle módon, többek közt belégzés útján mehet végbe. A jelen munkában kétféle méretú gömbszerú $\mathrm{TiO}_{2}$-nanorészecskével kezeltünk patkányokat, intratrachealis adagolással. Megvizsgáltuk, hogyan függ össze az elektrofiziológiai és magatartási módszerekkel kimutatott idegrendszeri funkcióváltozás a szöveti Ti-szintekkel és hogyan hat erre a részecskék mérete. Anyagok és módszerek - Fiatal felnőtt hím Wistarpatkányokat (hat csoport, 10-10 állat) kezeltünk heti öt napon, hat héten át, 10 és 100 nm körüli átmérőjiü $\mathrm{TiO}_{2}$ nanorészecskékkel, 1\% hidroxietil-cellulózt tartalmazó foszfátpufferelt fiziológiás oldatban szuszpendálva, 5 és 18 $\mathrm{mg} / \mathrm{ttkg}$ dózisban. A vivőanyagos kontrollcsoportot a szuszpendáló közeggel, míg a kezeletlen kontrollokat fiziológiás sóoldattal instilláltuk. Az általános toxicitást a testtömeg naponta történt mérésével, illetve a kísérlet végén a szervtömegek meghatározásával mutattuk ki. A motoros funkciók károsodását a hathetes kezelés előtt és annak végén végzett kapaszkodási próbával vizsgáltuk. Végül uretános altatásban kérgi alapaktivitást és szenzoros kiváltott potenciálokat vezettünk el, majd az állatokat felboncoltuk és szövetmintákat vettünk fémszint-meghatározásra.

Eredmények - A testtömeg-gyarapodás nem utalt általános toxicitásra, és relatív szervtömegre tett hatás csak a tüdőnél látszott. A kezelt állatokban azonban funkcionális károsodásra utaló változás volt a kapaszkodási próbánál a leesési időben, és a kérgi kiváltott potenciálok latenciáiában. Ezen változások és a kérgi Ti-szint korrelációja a kétféle méretú nanorészecske esetében eltérő volt. 
Conclusion - The results provided further support to the functional neurotoxicity of $\mathrm{TiO}_{2}$ nanoparticles. The exact role of particle size, and the mechanisms involved, remain to be elucidated.

Keywords: nanoparticles, titanium dioxide, neurotoxicity, tissue metal levels

$\mathrm{R}$ ecent advances in nanosciences and nanotechnology gave rise to numerous industrial processes and products based on nanoparticles (NPs) that is, particles with $<100 \mathrm{~nm}$ typical diameter. By now, NPs have been used among others in health care, energy production, agriculture and environmental protection ${ }^{1}$, which results in their release into the environment. In nanoparticulate state, substances show different physical and chemical properties than those seen in more conventional physical states, leading to biological, and hence, toxicological, interactions not seen with traditional materials, which also means novel health risks. When inhaled by humans, NPs are either deposited in the nasopharynx of or get down to the alveoli, and reach distant body parts by migration along fibres of the olfactory and other nerves, or by crossing the alveolar and capillary wall and entering systemic circulation $^{2}$. Generation of reactive oxygen species (ROS) and other surface reactions known to be crucial in the biological effects of NPs, are promoted by their high number and large specific surface area $^{3}$. Beyond that, NPs are known to migrate to mitochondria within the cells and directly interfere with oxidative phosphorylation, also resulting in ROS and finally in cell and tissue damage ${ }^{2}$.

$\mathrm{TiO}_{2}$ in NP form is a frequently applied engineered nanomaterial, present in coatings, and in skin care products like sunscreens, as radiation blocking agent ${ }^{4}$. Its anatase crystal form has photocatalytic properties in UV light which is utilized in antibacterial and anti-fouling applications, and in coatings and building materials that break down air pollutants ${ }^{5}$. This broad and growing range of application has raised questions about possible health risks $^{6}$, including nervous system damage ${ }^{7}$.

Chemical safety is a primary requirement today ${ }^{8}$, toxicological evaluation of novel materials should therefore take place not later than their introduction to everyday use. In occupational exposure to NPs, lung damage is the number one concern ${ }^{9}$, but regarding the known oxidative stress generating potency of $\mathrm{TiO}_{2}$ NPs (directly and via mitochondrial damage ${ }^{10}$ ) and the especial sensitivity of neu-
Következtetés - Az eredmények újabb érvet szolgáltatnak a $\mathrm{TiO}_{2}$-nanorészecskék funkcionális neurotoxicitása mellett. $A$ részecskeméret szerepe és a toxikus mechanizmus további vizsgálatokat igényel.

Kulcsszavak: nanorészecskék, titán-dioxid, neurotoxicitás, szöveti fémszintek

rons to oxidative stress (due to highly active mitochondrial energy production because of the high energy demand, to abundance of unsaturated structural lipids, and to low antioxidant defence capacity $^{11}$ ) - nervous system effects are also expected. In humans exposed to airborne titanium-based pigment particles at the workplace, neurological symptoms were indeed found ${ }^{12}$, but most results suggesting human nervous system affection came for in vitro investigations on cells ${ }^{13,14}$.

Rat-based models of nervous system effects of $\mathrm{TiO}_{2}$ NPs are scarce in the literature ${ }^{4}$. Inhalation exposure of rats to $10 \mathrm{mg} / \mathrm{m}^{3}$ nano- $\mathrm{TiO}_{2}$ aerosol (daily 6 hours, 5 days a week for 4 weeks) resulted in increased level of inflammation markers and decreased expression of synaptophysin in the brain without relevant deposition of $\mathrm{Ti}^{15}$. In most other rat studies using airway application, pulmonary toxicity was investigated ${ }^{16}$ and in some, the access of the NPs beyond the lungs was questioned ${ }^{17}$. On indirect application of $\mathrm{TiO}_{2} \mathrm{NPs}$ (young rats exposed during lactation via dam's milk who were treated orally) impaired synaptic plasticity in the dentate gyrus and significant Ti deposition in the hippocampus were found ${ }^{18}$. When adult rats received oral administration of $\mathrm{TiO}_{2} \mathrm{NPs}$, decreased brain acetylcholinesterase activity, together with increased GFAP reactivity and interleukin-6 level, was observed ${ }^{19}$. In a less realistic model - using intraperitoneal (ip.) injection - $\mathrm{TiO}_{2} \mathrm{NPs}$ given for 20 days resulted in increased anxiety in young Wistar rats, with elevated Ti level in brain and other organs and signs of cellular damage ${ }^{20}$.

Considering the above mentioned importance of airborne exposure and nervous system effects, in the present work rats were exposed to spherical $\mathrm{TiO}_{2}$ NPs of two different sizes via the airways by intratracheal (it.) instillation. Internal $\mathrm{Ti}$ exposure was determined, and functional neurotoxicity was investigated by electrophysiological and behavioral methods. It was also investigated how the neurofunctional alterations induced were related to the level of Ti in tissues and how these were influenced by the size and dose of the NPs. 


\section{Methods}

ANIMALS

Young adult SPF Wistar rats were used, altogether 60, obtained from Toxi-Coop Ltd. (Budapest, Hungary). The animals (with $170 \pm 20 \mathrm{~g}$ body weight at start) were kept in polypropylene cages (3-4 rats/cage) under GLP-equivalent conditions. (12-12 hours light/dark cycle with light on at 06:00; temperature $22-24{ }^{\circ} \mathrm{C}$; relative humidity $30-60 \%$ ). After one week of acclimation, the rats were randomized to 6 treatment groups of 10 rats each, on the basis of their body weight. The groups and corresponding treatments are shown in Table 1.

\section{PRODUCTION OF THE NANOPARTICLES}

All chemicals for the synthesis of NPs were obtained from Sigma-Aldrich.

Spherical $\mathrm{TiO}_{2}$ NPs of two sizes were synthesized, at the Department of Applied and Environmental Chemistry, Faculty of Science and Informatics, the following way:

To obtain NPs of ca. $10 \mathrm{~nm}$ diameter, titanium isopropoxide (TTIP, $7.32 \mathrm{~g}$ ) was added to $50 \mathrm{~mL}$ ethanol (absolute) and stirred for ten minutes. Another $20 \mathrm{~mL}$ ethanol was mixed in $165.5 \mathrm{~mL}$ distilled water and stirred simultaneously for the same duration. The ethanol-distilled water mix was then added by slow dropping (one drop in 5 seconds) to the TTIP solution being continuously stirred at high speed $(1200 \mathrm{rpm})$. After adding all the TTIP, stirring went on for half an hour. The $\mathrm{TiO}_{2} \mathrm{NPs}$ were collected from suspension by centrifuging and dried for 36 hours at $80^{\circ} \mathrm{C}$ in air; their final diameter was $9.67 \pm 1.66 \mathrm{~nm}$.

Larger NPs were prepared in a similar manner but other volumes and sequence was applied. 300 $\mathrm{mL}$ ethanol was added to $68.4 \mathrm{~mL}$ distilled water and stirred for 10 minutes. In this case the TTIP was given to the ethanol-water mix dropwise, at the same rate as mentioned above. These NPs had a diameter of $110 \pm 21.5 \mathrm{~nm}$.
The medium for suspending the dried NPs was phosphate-buffered saline (PBS, $\mathrm{pH}$ 7.4) containing $1 \%$ hydroxyethyl cellulose (HEC), both obtained from the pharmacy of the Faculty of Medicine of the University of Szeged.

\section{DOSES AND TREATMENT}

Rats in the control group ( $C$, see Table 1) received saline $(\mathrm{NaCl} 0.9 \%)$ and vehicle control (VC) rats received the medium described above (1\% HEC in PBS) by it. instillation. Treated rats received $\mathrm{TiO}_{2}$ NPs suspended in the medium; the two sizes of $\mathrm{TiO}_{2}$ NPs were administered in two doses as shown in Table 1. Treatment was done every workday (i.e., 5 days per week) over a 6 weeks period, between 8:00 and 10:00 a.m. It. instillation was performed in light volatile anesthesia as described $\mathrm{in}^{21}$. Our Ti doses were ca. one order of magnitude higher than that applied in a similar dosing regime in ${ }^{15}$ which $-10 \mathrm{mg} / \mathrm{m}^{3}$ for 6 hours - corresponds to ca. $1.25 \mathrm{mg} / \mathrm{kg}$ on the basis of ventilation volume data published in $^{16}$, and is itself higher than the 0.3 $\mathrm{mg} / \mathrm{m}^{3}$ occupational limit ${ }^{9}$.

\section{INVESTIGATIONS}

\section{General toxicity}

General toxicity of the instilled $\mathrm{TiO}_{2}$ NPs was characterized by the rats' body weight gain. Body weight was measured before every treatment to calculate the exact doses. From these data, individual weight gain for every rat over the whole treatment period was obtained as the difference between body weight on the last and first treatment day.

After the electrophysiological recording described below, each rat was sacrificed by the twofold of the anesthetic dose of urethane. From the group $V C$ and the metal-treated groups, 3 rats were randomly chosen for Ti level measurement. From these, a blood sample was taken from the left ventricle after opening the thorax, then the rat was transcardially perfused with $300 \mathrm{ml}$ saline of $4{ }^{\circ} \mathrm{C}$ temperature to

Table 1. Treatment groups, group coding, and treatments in the control and treated groups

\begin{tabular}{|llc|}
\hline Treatment Groups and Codes & Vehicle and volume & NP dose* \\
\hline Control (C) & saline, $1 \mathrm{ml} / \mathrm{kg} \mathrm{b} . \mathrm{w}$. & - \\
Vehicle Control (VC) & HEC-PBS, $1 \mathrm{ml} / \mathrm{kg} \mathrm{b.w.}$ & - \\
Small spherical NPs, low dose (S-LD) & HEC-PBS, $1 \mathrm{ml} / \mathrm{kg} \mathrm{b.w.}$ & $5 \mathrm{mg} / \mathrm{kg} \mathrm{b.w.}$ \\
Small spherical NPs, high dose (S-HD) & HEC-PBS, $1 \mathrm{ml} / \mathrm{kg} \mathrm{b.w.}$ & $18 \mathrm{mg} / \mathrm{kg} \mathrm{b.w.}$ \\
Large spherical NPs, low dose (L-LD) & HEC-PBS, $1 \mathrm{ml} / \mathrm{kg} \mathrm{b.w.}$ & $5 \mathrm{mg} / \mathrm{kg} \mathrm{b.w.}$ \\
Large spherical NPs, high dose (L-HD) & HEC-PBS, $1 \mathrm{ml} / \mathrm{kg} \mathrm{b.w.}$ & $18 \mathrm{mg} / \mathrm{kg} \mathrm{b.w.}$ \\
\hline
\end{tabular}

*The doses were based on previous experience ${ }^{24}$; with increases to achieve more clear-cut effects. 
remove blood from the organs. Samples of cerebral cortex and blood were stored at $-20{ }^{\circ} \mathrm{C}$. For measurement, the samples, after being dried to constant weight at $80{ }^{\circ} \mathrm{C}$, were digested in $3 \mathrm{~mL} \mathrm{cc}$. $\mathrm{HCl} / \mathrm{g}$ wet tissue for $90 \mathrm{~min}$ at $90{ }^{\circ} \mathrm{C}$, then an equal volume of cc. $\mathrm{HNO}_{3}$ was added for a further $90 \mathrm{~min}$ of digestion in order to fully dissolve all $\mathrm{TiO}_{2}$ particles. The liquid obtained was filtered on 0.45 mikrom hydrophilic membrane filter and diluted to $100 \mathrm{~mL}$ final volume. Ti level was determined by inductively coupled plasma mass spectrometry at the Department of Inorganic and Analytical Chemistry, University of Szeged Faculty of Science and Informatics. All other rats were dissected, the organs brain, heart, kidneys, adrenals, liver, lungs, spleen and thymus were weighed, and relative organ weights (to $1 / 100$ body weight) were calculated.

\section{Functional neurotoxicity}

The rats' motor function was assessed by the grip strength test ${ }^{22}, 23$. A wooden rod of ca. $8 \mathrm{~mm}$ diameter and rough surface was fixed horizontally in $60 \mathrm{~cm}$ height above a tray lined with a layer of wood chips litter. One by one, the rats were made grasp the rod with their front paws and let hang free. There were four trials in line for each rat and the length of time until falling was measured and averaged. Grip strength test was done before the treatment period $\left(0^{\text {th }}\right.$ week $)$ and two days after the last treatment ( $6^{\text {th }}$ week). For each rat, the average time-to-fall on the $6^{\text {th }}$ week was divided by the corresponding data of the $0^{\text {th }}$ week, and this ratio was used to quantify the effect of nano- $\mathrm{TiO}_{2}$.

Electrophysiological recording was done on the day following the $6^{\text {th }}$ week grip strength test. Preparation and recording was done in urethane anesthesia $1(1000 \mathrm{mg} / \mathrm{kg}$ b.w. ip, the level of anesthesia was checked by the hind leg withdrawal reflex). After mechanically fixing the skull, head skin was opened by a mid-sagittal cut, soft tissues were removed, and the left hemisphere was exposed by removing the temporal bone along the inner circumference by means of a mini drill. Wounds were sprayed with $10 \%$ lidocaine, the exposed cortex was protected with a thin layer of petroleum jelly, and the animal was put aside for at least $30 \mathrm{~min}$ for recovery. For recording, the rat was placed into the stereotaxic frame of the electrophysiological apparatus. For sustaining normal body temperature, a thermostated $\left(+36.5^{\circ} \mathrm{C}\right)$ base plate was used to support the rat's underside during the recording procedure. Silver electrodes were placed on the primary somatosensory (SS), visual (VIS) and auditory (AUD) areas. Spontaneous electrical activity was recorded from the sites for $6 \mathrm{~min}$, and the relative spectral power of the frequency bands was determined by the software used for electrophysiological recording and analysis (Neurosys 1.1, Experimetria Ltd., Hungary). Then, sensory stimulation in trains of 50 was applied (SS: electric stimuli to the contralateral whisker pad; 3-4 V, $0.05 \mathrm{~ms}$, 1,2 and $10 \mathrm{~Hz}$; VIS: flashes of a high-luminance LED to the contralateral eye, $0.2 \mathrm{~ms}, 1 \mathrm{~Hz}$; AUD: clicks, $70 \mathrm{~dB}, 1 \mathrm{~Hz}$ to the contralateral ear through the hollow ear bar of the stereotaxic frame). The cortical evoked potentials (EPs) were recorded, averaged automatically, and onset latency was measured manually.

During the whole study, the principles of the Ethical Committee for the Protection of Animals in Research of the University of Szeged were strictly followed. The methods used in this work were licensed by the authority competent in animal welfare issues under No. XXI./151/2013.

\section{Statistics}

The sufficient number of animals in the groups was calculated by means of Power analysis $(\mathrm{p} \geq 0.8)$. From the data, group means were calculated and checked for normality by the Kolmogorov-Smirnov test. Depending on the result of that, the main statistical test used was parametric one-way ANOVA or non-parametric Kruskal-Wallis method. Post hoc

Table 2. Body weight gain and relative organ weights (to $1 / 100$ body weight) in the control and treated groups

\begin{tabular}{|llllll|}
\hline Group code & Body weight gain $(\mathrm{g})$ & Brain & Lungs & Liver & Right kidney \\
\hline C & $139.4 \pm 26.8$ & $0.52 \pm 0.05$ & $0.35 \pm 0.02$ & $2.58 \pm 0.14$ & $0.31 \pm 0.02$ \\
VC & $154 \pm 17.1$ & $0.49 \pm 0.05$ & $0.50 \pm 0.05$ & $2.85 \pm 0.39$ & $0.32 \pm 0.05$ \\
S-LD & $146.6 \pm 21.3$ & $0.49 \pm 0.05$ & $0.58 \pm 0.06$ & $2.82 \pm 0.21$ & $0.32 \pm 0.05$ \\
S-HD & $163.7 \pm 19.9$ & $0.50 \pm 0.04$ & $0.58 \pm 0.07^{* * \# \#}$ & $2.86 \pm 0.45$ & $0.34 \pm 0.07$ \\
L-LD & $143.9 \pm 30$ & $0.49 \pm 0.03$ & $0.55 \pm 0.08$ & $2.85 \pm 0.24$ & $0.33 \pm 0.05$ \\
L-HD & $133.9 \pm 42.6$ & $0.48 \pm 0.06$ & $0.57 \pm 0.06$ & $2.87 \pm 0.30$ & $0.32 \pm 0.05$ \\
\hline
\end{tabular}

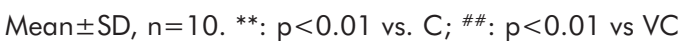




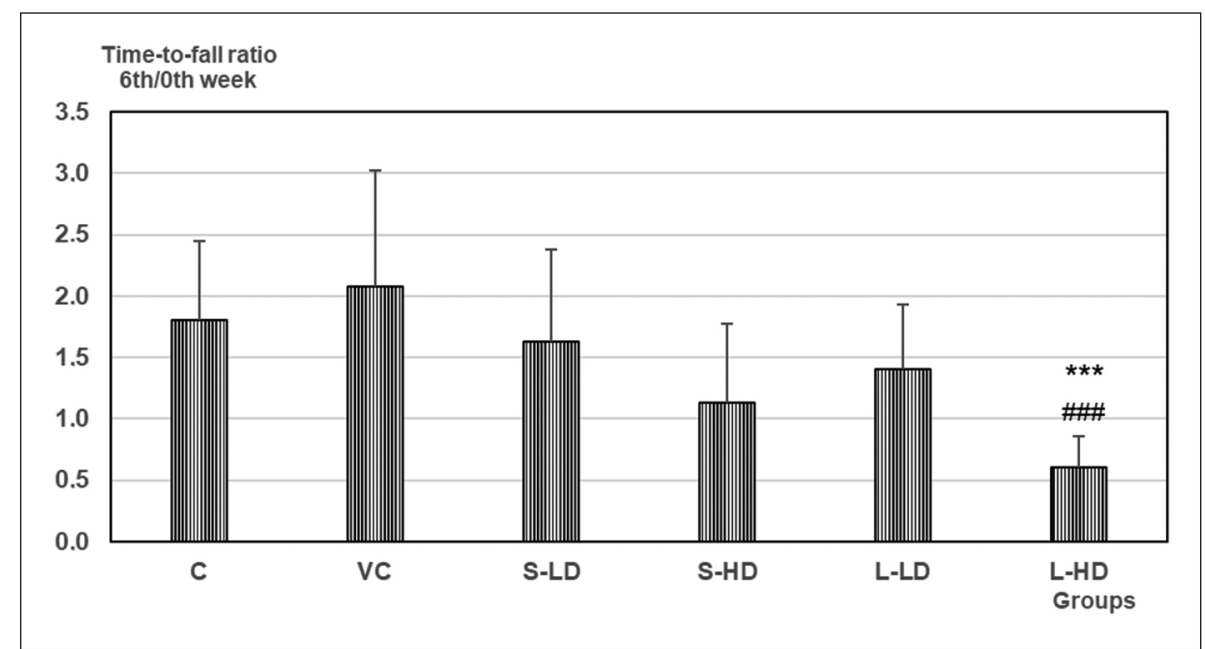

Figure 1. Ratio of the grip strength test time-to-fall in the $6^{\text {th }}$ and $0^{\text {th }}$ week (see Methods)

Mean+SD, n=10. *, **, ***: p<0.05, 0.01, 0.001 vs. C; \#, \#, \#\#\#: p<0.05, 0.01, 0.001 vs. VC

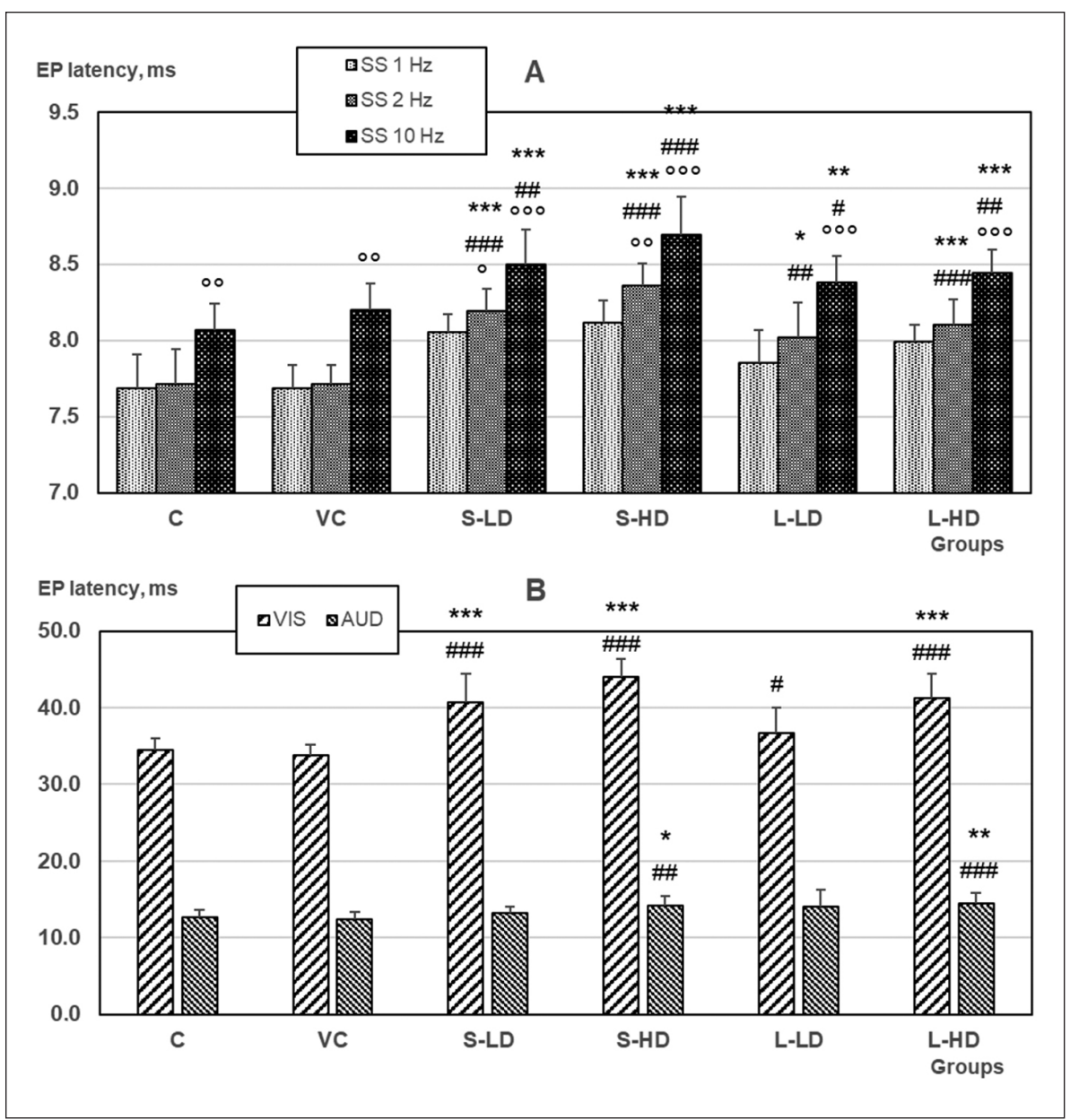

Figure 2. Latency times of the averaged EPs in the somatosensory (A) and the visual and auditory (B) modalities in the control and treated rat groups

Mean+SD, n=10. *,**,***: p<0.05, 0.01, 0.001 vs. C; \#, \#, \#\#\#: p<0.05, 0.01, 0.001 vs. VC; ${ }^{\circ},{ }^{\circ}{ }^{\circ}$ : p $<0.01$, 0.001 vs. $1 \mathrm{~Hz}$ stimulation in the same group analysis of group differences was done by Tukey test and the Mann-Whitney U test. SPSS 24.0 (IBM Corporation, U.S.A.) was used.

\section{Results}

As judged from the group mean data of body weight gain, 6 weeks of $\mathrm{TiO}_{2} \mathrm{NP}$ exposure exerted no general toxicity in the treated rats (Table 2). Also, among the organs, only the lungs appeared to be affected; their relative weight reflected the effect of the treatment procedure (group $V C$ vs. $C$ ) and of the $\mathrm{TiO}_{2} \mathrm{NP}$ exposure.

In the grip strength test, the decrease of time-to-fall from the $0^{\text {th }}$ to the $6^{\text {th }}$ week (indicated by the $6^{\text {th }}$ week / $0^{\text {th }}$ week ratio; Figure 1) was stronger in the treated rats, with significant change in the $L-H D$ group.

Among the electrophysiological phenomena recorded, spontaneous cortical activity was slightly shifted to higher frequencies in the treated rats (not shown). EP latency, however, was substantially lengthened on exposure to $\mathrm{TiO}_{2} \mathrm{NPs}$, and in groups $S-H D$ and $L-H D$ the change was significant vs. $C$ and $V C$ (Figure 2).

The causal relationship between $\mathrm{TiO}_{2}$ NP exposure and the mentioned functional alterations, suggested by the group-bygroup dose dependence of the changes, was further tested by examining the correlation of cortical $\mathrm{Ti}$ levels, and corresponding parameters of EP latency 


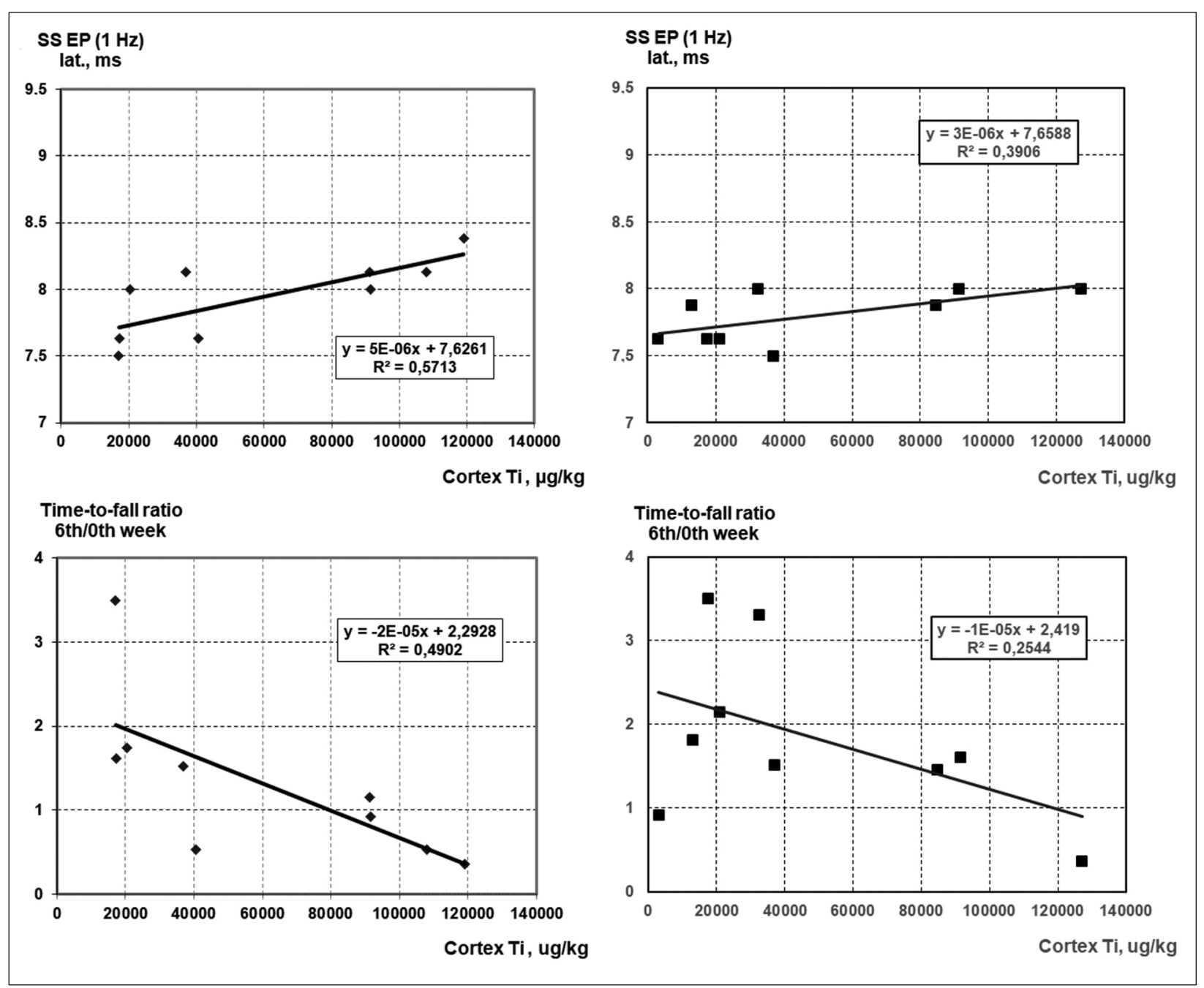

Figure 3. Correlation diagrams of the somatosensory evoked potential latency to cortical Ti level in rats treated with the smaller (left column) and larger (right column) $\mathrm{TiO}_{2} \mathrm{NPS}$

(Figure 3) and grip strength test time-to-fall ratio (Figure 4). Although Ti measurement was done only on 3 rats' samples per group, the diagrams show mostly fair correlations. The data show also that the effect of the smaller sized NPs was in most cases more clear-cut, resulting in relatively higher $\mathrm{R}^{2}$ values.

\section{Discussion}

The neuro-functional alterations seen in the treated rats, and the correlation of these with the individual cortical Ti levels, pointed to the possible causative role of some $\mathrm{TiO}_{2}$ NP-dependent processes. Most probably, mitochondrial damage and oxidative stress were involved, both known to be present in cells and tissues in NP exposure ${ }^{2}$. In rats undergo- ing artificial cerebral hypoxia-reperfusion, oxidative stress indicators increased (including lipid peroxidation, seen also in a previous work of us $^{24}$ with $\mathrm{TiO}_{2}$ NPs) and muscle force, examined by grip strength test, decreased ${ }^{25}$. This is in parallel with our findings in nano- $\mathrm{TiO}_{2}$ treated rats in the mentioned and the present study.

Latency lengthening of the EPs could result both from mitochondrial lesion and oxidative damage. The input-output relationship in ${ }^{18}$ indicated impaired synaptic function in the nano- $\mathrm{TiO}_{2}$ exposed rats. Decreased level of synaptophysin in rats after inhalation of nano- $\mathrm{TiO}_{2}$, as described in ${ }^{15}$ also suggests the role of impaired transmission in EP latency lengthening observed in our work. Beyond that, oxidative damage of membrane constituents, mainly lipids ${ }^{11}$, impairs membrane-bound functions including synaptic transmission. In rats exposed the 


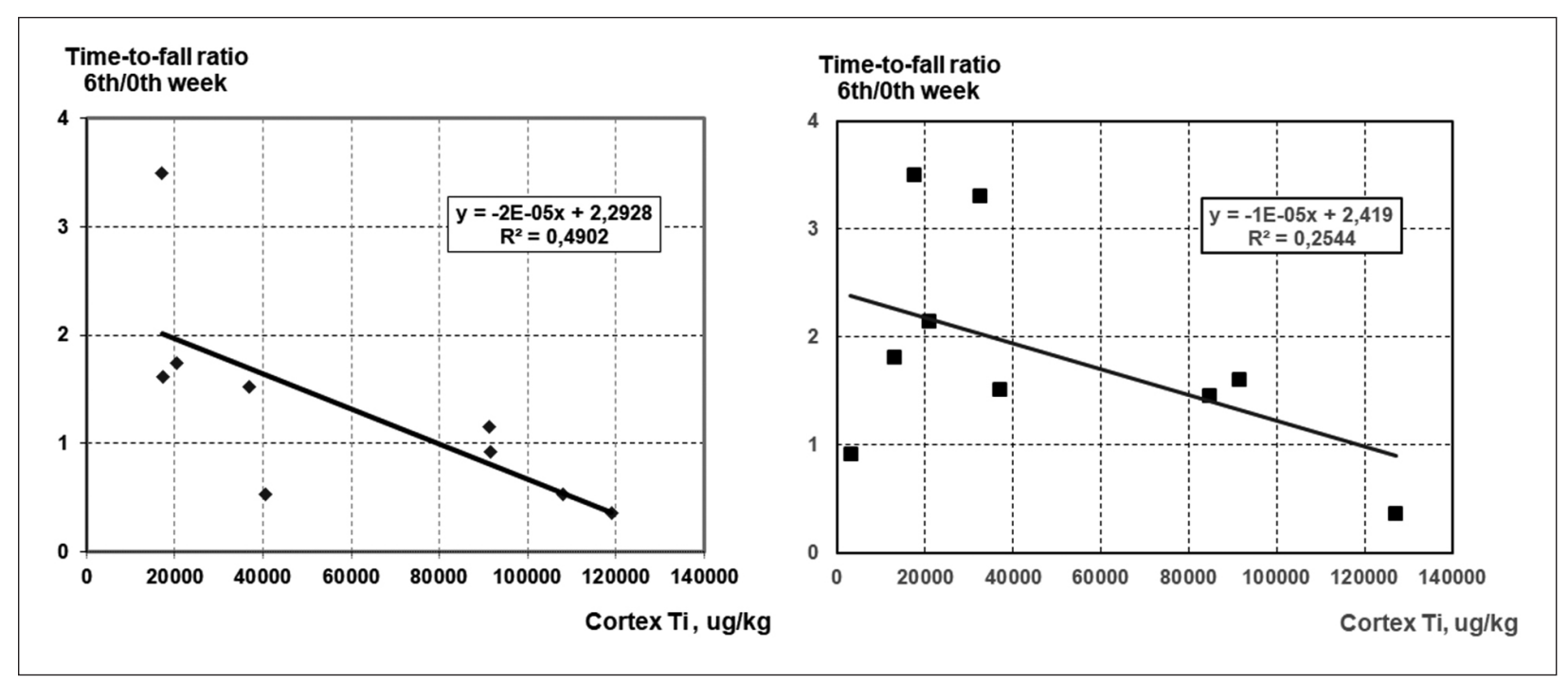

Figure 4. Correlation diagrams of the time-to-fall ratio in the grip strength test to cortical Ti level in rats treated with the smaller (left) and larger (right) $\mathrm{TiO}_{2} \mathrm{NPs}$

same way with another metal oxide NPs, nano$\mathrm{MnO}_{2}$, lengthening of EP latency in the treated rats was reversed by antioxidant treatment ${ }^{26}$ supporting the above described mechanism of NP-induced neuro-functional damage.

Mitochondrial damage leads to energy shortage in neuronal and glial cells. Glutamate is co-transported into the astrocytes with $\mathrm{Na}^{+}$along its concentration gradient which can be degraded if ion pumps do not operate properly due to energy shortage, ending up with excess perisynaptic glutamate and disturbed transmission ${ }^{27}$. Together with impaired axonal conduction this can result in depressed impulse propagation manifested in delayed cortical response to a peripheral stimulus.

The data in Figure $\mathbf{1}$ and $\mathbf{2}$ suggest that at equal mass dose the smaller NPs had a stronger effect on cortical EPs, and the larger ones, on grip strength. One can suppose that $10 \mathrm{~nm} \mathrm{TiO}_{2}$ NPs had higher chance to reach the brain and $100 \mathrm{~nm}$ NPs stayed more in the peripheral circulation affecting nerves and muscles. With iridium NPs inhaled by rats, ca. 5 times less translocation of $75 \mathrm{~nm}$ size NPs than of $10 \mathrm{~nm}$ ones from the lungs to liver and kidneys was reported $^{28}$, underlining the effect of NP size on crossing barriers. Likewise, breakdown of bloodbrain barrier and neuronal damage caused by metal

\section{REFERENCES}

1. Buzea C, Pacheco Blandino II, Robbie K. Nanomaterials and nanoparticles: Sources and toxicity. Biointerphases 2007;2:MR17-MR172. https://doi.org/10.1116/1.2815690

2. Oberdörster G, Oberdörster E, Oberdörster J. Nano-
NPs, given ip., was more severe with 20-30 nm than with 56-60 $\mathrm{nm}$ or $>100 \mathrm{~nm}$ particles ${ }^{29}$. Blood-brain barrier damage was also observed in rats that inhaled nano- $\mathrm{Ti}^{15}$.

The present study left a few questions open. It remains to be clarified, by electron microscopy, whether and to what extent the chemically measured Ti content of the organ (first of all brain) samples indicates the presence of $\mathrm{TiO}_{2}$ NPs. Likewise, the actual role of the putative toxic mechanisms, especially in the periphery, awaits further investigations.

\section{Conclusion}

The results provided further support to the functional neurotoxicity of $\mathrm{TiO}_{2}$ nanoparticles, including central and peripheral actions. The exact role of particle size, and the mechanisms involved, remains to be elucidated.

\section{ACKNOWLEDGMENTS}

The authors are thankful to Prof. Gábor Galbács and co-workers (Department of Inorganic and Analytical Chemistry, University of Szeged Faculty of Science and Informatics) for Ti level determination. toxicology: An emerging discipline evolving from studies of ultrafine particles. Environ Health Perspect 2005;113: 823-39.

https://doi.org/10.1289/ehp.7339 
3. Nel A, Yia T, Mädler L, Li N. Toxic potential of materials at the nanolevel. Science 2006;311:622-27. https://doi.org/10.1126/science.1114397

4. Czajka M, Sawicki K, Sikorska K et al. Toxicity of titanium dioxide nanoparticles in central nervous system. Toxicol In Vitro 2015;29:1042-52.

https://doi.org/10.1016/j.tiv.2015.04.004

5. Chen J, Poon C. Photocatalytic construction and building materials: From fundamentals to applications. Building Environ 2009;44:1899-906. https://doi.org/10.1016/j.buildenv.2009.01.002

6. Grande F, Tucci P. 2016. Titanium dioxide nanoparticles: a risk for human health? Mini Rev Med Chem 2016;16: 762-9. https://doi.org/10.2174/1389557516666160321114341

7. Migliore L, Uboldi C, Di Bucchianico S, Coppede F. Nanomaterials and neurodegeneration. Environ Mol Mutagen 2015;56:149-70. https://doi.org/10.1002/em.21931

8. SCENIHR (Scientific Committee on Emerging and Newly Identified Health Risks). Risk assessment of products of nanotechnologies, 19 January 2009.

http://ec.europa.eu/health/ph_risk/committees/04_ scenihr/docs/scenihr_o_023.pdf (Letöltés ideje: 2017. november 17.)

9. NIOSH. Occupational Exposure to Titanium Dioxide. Current Intelligence Bulletin 63. Department of Health and Human Services (National Institute of Occupational Safety and Health) Publication No. 2011-160.

http://www.cdc.gov/niosh/docs/2011-160/ (Letöltés ideje: 2017. november 17.)

10. Nalika N, Parvez S. Mitochondrial dysfunction in titanium dioxide nanoparticle-induced neurotoxicity. Toxicol Mech Meth 2015;25:355-63. https://doi.org/10.3109/15376516.2015.1020183

11. Guerra-Araiza C, Álvarez-Mejía AL, Sánchez-Torres $S$, Farfan-García E, Mondragón-Lozano R, Pinto-Almazán R, et al. Effect of natural exogenous antioxidants on aging and on neurodegenerative diseases. Free Rad Res 2013;47:45162. https://doi.org/10.3109/10715762.2013.795649

12. Oleru $U G$. Respiratory and nonrespiratory morbidity in a titanium oxide paint factory in Nigeria. Am J Ind Med 1987;12:173-80. https://doi.org/10.1002/ajim.4700120206

13. Coccini T, Grandi S, Lonati D, Locatelli $C$, De Simone U. Comparative cellular toxicity of titanium dioxide nanoparticles on human astrocyte and neuronal cells after acute and prolonged exposure. Neuro Toxicology 2015;48:77-89. https://doi.org/10.1016/j.neuro.2015.03.006

14. Valdiglesias V, Costa C, Sharma V, Kiliç G, Pásaro E, Teixeira JP, et al. Comparative study on effects of two different types of titanium dioxide nanoparticles on human neuronal cells. Food Chem Toxicol 2013;57:352-61. https://doi.org/10.1016/j.fct.2013.04.010

15. Disdier C, Chalansonnet M, Gagnaire F, Gaté L, Cosnier $F$, et al. Brain inflammation, blood brain barrier dysfunction and neuronal synaptophysin decrease after inhalation exposure to titanium dioxide nano-aerosol in aging rats. Scientific Report S 2017;7:12196. https://doi.org/10.1038/s41598-017-12404-5

16. Yoshiura Y, Izumi H, Oyabu T, Hashiba M, Kambara T, Mizuguchi $Y$, et al. Pulmonary toxicity of well-dispersed titanium dioxide nanoparticles following intratracheal instillation. J Nanopart Res 2015;17:241. https://doi.org/10.1007/s11051-015-3054-X
17. Baisch BL, Corson NM, Wade-Mercer P, Gelein R, Kennell $A J$, Oberdörster $G$, et al. Equivalent titanium dioxide nanoparticle deposition by intratracheal instillation and whole body inhalation: the effect of dose rate on acute respiratory tract inflammation. Part Fibre Toxicol 2014;11:5. https://doi.org/10.1186/1743-8977-11-5

18. Gao X, Yin S, Tang M, Chen J, Yang Z, Zhang $W$ et al. Effects of developmental exposure to $\mathrm{TiO}_{2}$ nanoparticles on synaptic plasticity in hippocampal dentate gyrus area: an in vivo study in anesthetized rats. Biol Trace Elem Res 2011;143:1616-28. https://doi.org/10.1007/s12011-011-8990-4

19. Grissa I, Guezguez S, Ezzi L, Chakroun S, Sallem A, Kerkeni $E$, et al. The effect of titanium dioxide nanoparticles on neuroinflammation response in rat brain. Environ Sci Pollut Res Int 2016;20:20205-13. https://doi.org/10.1007/s11356-016-7234-8

20. Ben-Younes NR, Amara S, Mrad I, Ben-Slama I, Jeljeli M, et al. Subacute toxicity of titanium dioxide (TiO2) nanoparticles in male rats: emotional behavior and pathophysiological examination. Environ Sci Pollut Res 2015;22: 8728-37.

https://doi.org/10.1007/s11356-014-4002-5

21. Oszlánczi G, Horváth E, Szabó A, Horváth E, Sápi A, Kozma $G$, et al. Subacute exposure of rats by metal oxide nanoparticles through the airways: general toxicity and neuro-functional effects. Acta Biol Szeged 2010;54:16570.

22. Strohl KP, Thomas AJ, St.Jean P, Schlanker EH, Koletsky $R J$, Schork NJ. Ventilation and metabolism among rat strains. J Appl Physiol 1997;82:317-23.

23. Feng $Q, M a Y, M u S$, Wu J, Chen S, Ou-Yang L, Lei W. (2014) Specific reactions of different striatal neuron types in morphology induced by quinolinic acid in rats. PLoS ONE 2014;9:e91512. https://doi.org/10.1371/journal.pone.0091512

24. Horváth T, Papp A, Kovács D, Kálomista I, Kozma G, Vezér T. Electrphysiological alterations and general toxic signs obtained by subacute administration of titanium dioxide nanoparticles to the airways of rats. Ideggyogy $\mathrm{Sz}$ 2017;70:127-35. https://doi.org/10.18071/isz.70.0127

25. Tabassum R, Vaibhav K, Shrivastava P, Khan A, Ahmed E, Javed $H$ et al. Centella asiatica attenuates the neurobehavioral, neurochemical and histological changes in transient focal middle cerebral artery occlusion rats. Neurol Sci 2013;34:925-33. https://doi.org/10.1007/s10072-012-1163-1

26. Sárközi K, Papp A, Horváth E, Máté Zs, Hermesz E, Kozma $G$ et al. Protective effect of green tea against neuro-functional alterations in rats treated withMnO2 nanoparticles. J Sci Food Agric 2017;97:1717-24. https://doi.org/10.1002/jsfa.7919

27. Takahashi M, Billups B, Rossi D, Sarantis M, Hamann $M$, Attwell $D$. The role of glutamate transporters in glutamate homeostasis in the brain. J Exp Biol 1997;200:401-9.

28. Buckley A, Warren J, Hodgson A, Marczylo T, Ignatyev K, Guo $C$. Slow lung clearance and limited translocation of four sizes of inhaled iridium nanoparticles. Part Fibre Toxicol 2017; 14:5 https://doi.org/10.1186/s12989-017-0185-5

29. Sharma A, Muresanu DF, Patnaik R, Sharma HS. Size- and age-dependent neurotoxicity of engineered metal nanoparticles in rats. Mol Neurobiol 2013;48:386-96. https://doi.org/10.1007/s12035-013-8500-0 